MIECZYSŁAW JAGŁOWSKI

Uniwersytet Warmińsko-Mazurski w Olsztynie

\title{
SYSTEM KORPORACYJNY PORTUGALSKIEGO NOWEGO PAŃSTWA $(1933-1974)^{1}$
}

Zarys treści: W artykule zakreślono historyczną i strukturalną panoramę portugalskiego systemu korporacyjnego okresu Nowego Państwa (1933-1974), odnosząc ją do politycznego - portugalskiego i europejskiego - kontekstu jego funkcjonowania. Przywołano argumentację Antónia de Oliveiry Salazara, głównego konstruktora owego systemu i ustroju Nowego Państwa, za jego utworzeniem oraz opinie głównych portugalskich sił politycznych i społecznych w odniesieniu do tej idei. Ukazano także ekonomiczne, polityczne i społeczne skutki funkcjonowania systemu korporacyjnego w Portugalii oraz nakreślono okoliczności jego likwidacji po rewolucji goździków (1974).

The content outline: The article outlines a historical and structural panorama of the Portuguese corporate system in the period of the New State (1933-1974), in reference to the political, Portuguese and European context of its functioning. Arguments of António de Oliveira Salazar are brought up, the chief architect of this system and form of government of the New State, for its establishment, and opinions of the main Portuguese political and social forces about the idea. There are also economic, political and social effects of the corporate system presented, together with the circumstances of its abolishment after the Carnation Revolution (1974).

Słowa kluczowe: Portugalia, Nowe Państwo (1933-1974), salazaryzm, korporacjonizm, António de Oliveira Salazar (1889-1970), Marcello Caetano (1906-1980), rewolucja goździków (1974)

Keywords: Portugal, New State (1933-1974), Salazarism, corporatism, António de Oliveira Salazar (1889-1970), Marcello Caetano (1906-1980), Carnation Revolution (1974)

${ }^{1}$ Artykuł powstał w ramach grantu OPUS 14 Narodowego Centrum Nauki, nr 2017/27/B/HS1/00234. 


\section{Uwagi wstępne}

Po I wojnie światowej w niektórych krajach europejskich (m.in. Włochy, Austria, Portugalia) pojawiła się tendencja do instytucjonalizacji mechanizmów negocjacji zbiorowych układów pracy między pracownikami i pracodawcami, w której państwu wyznaczano rolę gwaranta zawieranych porozumień i umów. Miała ona na celu wykroczenie poza wolny rynek pracy, ukształtowany przez dziewiętnastowieczny liberalizm ekonomiczny i polityczne struktury państwa liberalnego oraz skanalizowanie konfliktów między pracą i kapitałem. Idea ta przybrała formę dążeń do ustanowienia korporacyjnej struktury społecznej i politycznej państwa. „Rojaliści, republikanie, technokraci, faszyści i katolicy społeczni w wielkiej mierze stali na wspólnym gruncie w odniesieniu do pojmowania demokracji i reprezentacji politycznej oraz projektu reprezentacji funkcjonalnej jako alternatywy dla demokracji liberalnej”'. Tego rodzaju rozwiąania polityczne w Europie nie były wówczas uznawane za niezgodne z prawem konstytucyjnym. Mieściły się one w ogólnym nurcie racjonalizacji systemu władzy, zmierzajaccej do zawarcia w konstytucjach zasad odrzucających podział władz (sądzono bowiem, że jest on czynnikiem politycznej i społecznej destabilizacji) oraz wzmocnienia władzy wykonawczej przez ograniczenie zwierzchności zgromadzeń ustawodawczych. W latach 20. i 30. XX w. korporacjonizm był rozważany jako polityczna, ekonomiczna i społeczna alternatywa, zdolna do przezwyciężenia dominujących systemów liberalnego kapitalizmu i komunistycznego socjalizmu. W owych czasach niepewności i kryzysu myśli ekonomicznej korporacjonizm, rozumiany zarówno jako filozofia społeczna, jak i ekonomia polityczna, wywołał intensywną dyskusję. Idea ta pojawiała się w teoriach racjonalnej organizacji państwa oraz w myśli ekonomicznej, w debatach nad granicami samoregulacji rynku i kryzysem państwa liberalnego.

Jako pierwszy powstał system korporacyjny w faszystowskim państwie włoskim (1926), stając się, jako realnie istniejacy, punktem odniesienia dla systemów ustanawianych później w innych krajach. Ważnym elementem kontekstu dażeń zmierzających do rozwiązań korporacyjnych była także rewolucja październikowa w Rosji. Korporacjonizm zaczą być

2 A. Costa Pinto, Corporatism and Dictatorships in Portugal and Spain. Comparative Perspectives, w: Cola, Zeitgeschichte: Oliver Rathkolb und das lange 20. Jahrhundert, t. 1, red. L. Dreidemy, R. Hufschmied, A Meisinger i in., Wien 2015, s. 492 (jeśli nie zaznaczono inaczej, tłumaczenia sa dziełem autora); A. Gagliardi, The Corporatism of Fascist Italy between Words and Reality, „Estudos Ibero-Americanos” 42, 2016, nr 2, s. 414-415. 
wówczas postrzegany również jako zapora przed zagrożeniem komunistycznym. Niechęć zwolenników korporacjonizmu do związków zawodowych i korporacji o charakterze socjalistycznym wynikała z ich obaw, że będą one „koniem trojańskim”, którego wprowadzenie do systemu korporacyjnego okaże się posiewem przyszłej rewolucji ${ }^{3}$.

Pragnienie wykluczenia lewicowego syndykalizmu robotniczego prowadziło zwolenników syndykalizmu do podjęcia zagadnienia selekcji aktorów [systemu korporacyjnego - M.J.], a to, z kolei, do postawienia kwestii roli państwa. [...] konieczne okazuje się istnienie 'arbitra', udzielającego 'licencji' tym, którzy mogą w nim partycypować oraz wykluczajacego tych, którzy tego czynić nie powinni [...] korporacjoniści uznaja, że tylko państwo ma władzę i wystarczające środki do wypełnienia tego zadania ${ }^{4}$.

Na przełomie XIX i XX w. za systemem korporacyjnym opowiadały się chyba wszystkie opcje polityczne ${ }^{5}$, jednak najwyraźniej partie prawicowe i katolicyzm społeczny. Myśl tę można łatwo odnaleźć w ideologiach takich ruchów i organizacji nacjonalistycznych jak Alldeutscher Verband (zał. w 1891 r.), Action Française (zał. w 1898 r.), Associazione Nazionalista Italiana (zał. w 1910 r.) czy Integralismo Lusitano (zał. w 1914 r.). „Organizacje te podzielały organicystyczną koncepcję

3 A. Costa Pinto, M.I. Rezola, Political Catholicism, Crisis of Democracy and Salazar's New State in Portugal, ,Totalitarian Movements and Political Religions” 8, 2007, nr 2, s. 355.

${ }^{4}$ F. Bernal García, Corporativismo y Fascismo. Los sistemas de relaciones laborales autoritarios en la Europa de entreguerras, „Hispania Nova” 15, 2017, s. 51; zob. A. Łabno, Konstytucja Portugalii z 1933 roku na tle rozwoju portugalskiego konstytucjonalizmu, w: Franco i Salazar. Europejscy dyktatorzy, red. M. Słęcki, B. Szklarski, Warszawa 2012, s. 225.

${ }^{5}$ Korporacjonizm często bywa postrzegany jako ściśle związany z niedemokratycznymi, autorytarnymi systemami politycznymi. Bywał on jednak rozważany także przez myśl polityczną odległa od tego rodzaju ideałów politycznych. Przykładem może być brytyjski New Age Circle, grupa złożona z pisarzy i intelektualistów (m.in. A.R. Orage, A.J. Penty, F.W. Maitland, J.N. Figgis, H.E. Manning, bracia G. i C. Chesterton, H. Belloc, R. de Maeztu). W latach 1907-1916 środowisko to prowadziło ożywione debaty polityczne, nawiązując zwłaszcza do dwóch dziewiętnastowiecznych myślicieli brytyjskich, W. Morrisa i J. Ruskina, którzy wypracowali ideę specyficznego socjalizmu, opozycyjnego w stosunku do liberalizmu, kapitalizmu i indywidualizmu, przyjmując za wzór organizacji społecznej i politycznej wyidealizowane, harmonijne stosunki społeczne i polityczne średniowiecznej rolniczej Anglii. Grupa ta wyrażała postawy antypozytywistyczne, antyliberalne i antyparlamentarne, była brytyjska odmiana europejskiej reakcji na materializm i marksistowski socjalizm, odrzucała ich naukowe uzasadnienia na rzecz stanowiska etycznego i organicystycznego; zob. V. Torreggiani, Rediscovering the Guild System. The New Age Circle as a British Laboratory of Corporatist Ideas (1906-1916), „Oficina do Historiador” 9, 2016, nr 2, 34-35. 
narodu, według której powinien on być rozumiany jako ciało złożone z pewnej liczby 'organów', w którym każdy spełnia jakaśs funkcję. By naród osiagnał pełnię, nieodzowne jest, by organy te działały harmonijnie, ponieważ konflikt między nimi powoduje jedynie ich osłabienie"6. Korporacjonistyczna postawa katolicyzmu społecznego uzyskała natomiast wsparcie w encyklice papieża Leona XIII pt. Rerum novarum (1891), zawierającej wyraźnie zarysowany organicystyczny obraz społeczeństwa oraz ideę harmonijnej współpracy kapitału i pracy, wskazywanej jako fundamentalny warunek porządku społecznego. Korporacyjna organizacja społeczeństwa była na jej gruncie prezentowana jako wyraz zdolności społeczeństwa do samostanowienia. Korporacjom, jako „naturalnym” bytom społecznym, przyznawała ona prawa, których nie powinno naruszać państwo. Potwierdzeniem tych idei była ogłoszona przez Piusa XI encyklika Quadragesimo anno (1931).

Chociaż perspektywa korporacjonistyczna była wówczas przekonująca dla wielu ludzi (zwłaszcza po katastrofie liberalnej ekonomii w 1929 r.), to jednak istniały znaczące różnice w rozlicznych sformułowaniach dotyczacych systemu korporacyjnego, np. proponowany przez Kościół katolicki odbiegał znacznie od jego rozumienia faszystowskiego czy tego, za którym opowiadała się skrajna prawica. Mimo że „wielu ideologów korporacjonizmu - w szczególności w kręgach katolickich - opowiadało się za korporacjonizmem społecznym bez wszechobecnego państwa, to jednak wdrożenie korporacyjnych wzorców reprezentacji było głównie skutkiem ich narzucenia przez autorytarne elity polityczne społeczeństwu obywatelskiemu"?.

W artykule omawiam polityczne okoliczności wdrożenia i funkcjonowanie systemu korporacyjnego portugalskiego Nowego Państwa, stanowiącego jedną z najdłużej trwających w nowoczesnej Europie (ponad 40 lat) struktur społeczno-politycznych tego rodzaju. W polskiej literaturze poświęcono temu zagadnieniu niewiele uwagi, poprzestając, w kilku tekstach, w jakich je podjęto, na dość ogólnym naszkicowaniu struktury owego systemu, pozostawiając czytelników (należy do nich także autor tego artykułu) z niedosytem poznawczym i potrzebą pogłębienia wiedzy na jego temat. Idąc $\mathrm{w}$ tym kierunku, przedstawiam $\mathrm{w}$ artykule kontekst społeczny i ideologiczny wprowadzenia systemu korporacyjnego w Portugalii, przytaczając argumenty, które za wprowadzeniem systemu korporacyjnego formułował jego główny orędownik i twórca (a także główny beneficjent) - António de Oliveira Salazar (1889-1970).

\footnotetext{
${ }^{6}$ F. Bernal García, dz. cyt., s. 50

${ }^{7}$ A. Costa Pinto, dz. cyt., s. 494.
} 
Przywołuję również głosy krytyków tego projektu. Następnie omawiam ustanowioną w $1933 \mathrm{r}$. strukturę korporacyjną portugalskiego państwa, charakteryzuję jego ogniwa i instytucje, wskazujacc na akty prawne, na mocy których została ona ustanowiona i podlegała przemodelowaniom. Przywołuję także postawy, jakie przyjmowały wobec niej najbardziej politycznie aktywne portugalskie środowiska społeczne, opcje ideologiczne i grupy zawodowe. Na podstawie poczynionych w artykule ustaleń wskazuję społeczne konsekwencje funkcjonowania w Portugalii korporacyjnej organizacji życia politycznego, ekonomicznego i społecznego.

\section{Kontekst ideologiczno-społeczny portugalskiego korporacjonizmu}

W języku portugalskiej kultury naukowej i politycznej słowo „korporacja” pojawiło się w XIX stuleciu. Oznaczało ono organizm polityczny mający na celu regulowanie relacji między jednostkami i państwem. Nowsze pochodzenie miała kategoria „korporacjonizm”, znajdująca się w częstym użyciu w dyskursie politycznym w Hiszpanii, Francji, Szwajcarii, Austrii, Niemczech i Italii. Nie miała ona precyzyjnego znaczenia. Jej określenie odnosiło się zarówno do pokojowego rozwiązywania konfliktów między kapitałem i praca, zwalczania ideologii marksistowskiej, jak i do nowych form regulacji ekonomicznej i społecznej.

W XIX w. w Portugalii ideę korporacjonizmu eksponował zwłaszcza wybitny, romantyczny pisarz i historyk Alexandre Herculano (1810-1877). Wskazywał on średniowiecze jako złotą epokę w dziejach kraju, a wśród źródeł jego świetności wyróżniał powstanie municypiów, „organicznych”, autonomicznych jednostek samoorganizacji społecznej, które, jak twierdził, stanowiły gwarancję niezależności ludu w obliczu nadużyć klas uprzywilejowanych oraz skutecznie równoważyły sprzeczności między społeczna nierównościa i wolnościa. Idee te „krążyły wśród elit partii politycznych, stowarzyszeń obywatelskich, były obecne w myśli niezrzeszonych intelektualistów, prowadząc do pojawiania się propozycji nowych form organizacyjnych reprezentacji, odpowiadając na rozwiązanie kwestii relacji między indywidualizmem a solidaryzmem"8. Ponieważ

${ }^{8}$ F. Catroga, Natureza e história na fundamentação do municipalismo da revolução liberal ao Estado Novo (uma sintese), w: Studos em homenagem a Luís António de Oliveira Ramos, red. J. Martins Ribeiro, F. Ribeiro da Silva, H. Osswald, Porto 2004, s. 409; P.A. Guerreiro Martins, Uma época de grandeza. Idade média, decadência e regeneração na historiografia portuguesa (1842-1942), „Revista de Teoria da História” 17,2017 , nr 1, s. 39. 
zasady demokracji liberalnej wyrażajace się w formie systemu partyjnego i powszechnego prawa wyborczego były postrzegane jako atomizujące społeczeństwo, postulowano przywrócenie jego politycznej reprezentacji korporacyjnej. Ideę tę popierali antyliberalni monarchiści, była ona obecna w ideologiach ruchów nacjonalistycznych, sympatie wobec niej manifestował portugalski katolicyzm, zawierały ją także programy polityczne partii republikańskich. Nawet ci, którzy sami siebie zaliczali do skrajnej lewicy, dostrzegając nadmierny wpływ interesów partyjnych na legislację, w latach 20. XX w. postulowali utworzenie drugiej izby parlamentu, w której reprezentowane byłyby interesy grup zawodowych. Tak więc „powszechna reakcja ideologiczno-polityczna kierowała się przeciwko koncepcjom liberalnym, czysto indywidualistycznym, oraz przeciw wyłącznej reprezentacji politycznej za pośrednictwem partii politycznych, opowiadając się za powrotem struktur stowarzyszeniowych, reprezentujacych życie organiczne i wspólnotowe"9.

Jedna z najbardziej politycznie wpływowych wizji ustanowienia systemu reprezentacji korporacyjnej wygenerował ruch Integralismo Lusitano. Swoje stanowisko polityczne integraliści określali jako konserwatywne, tradycjonalistyczne, nacjonalistyczne, antykapitalistyczne, antydemokratyczne i antyparlamentarne. Ich przewodnią myślą była idea powrotu do tradycyjnej koncepcji państwa-narodu, skierowana przeciw jego liberalnemu rozumieniu, zakładającemu system demokracji parlamentarnej, która, jak twierdzili, niszczy porządek społeczny i jest triumfem przeciętności. Społeczeństwu demokratycznemu, jako rzeczywistości zatomizowanej i zdezorganizowanej, przeciwstawiali oni pojęcie narodu jako trwałego bytu społecznego, który tworzą nie jednostki, lecz „organiczne” grupy społeczne, przede wszystkim rodziny, będące kontynuatorkami cnót przodków, związane z własnością ziemska, która zabezpiecza je przed zmiennością fortuny ${ }^{10}$.

9 E. Castro Leal, Tradições organicistas. Ideias políticas e práticas de representação, „Espacio, Tiempo y Forma. Serie V. Historia Contemporánea” 27, 2015, s. 39.

${ }_{10}$ Tenże, Nacionalismo e antiliberalismo em Portugal. Uma visão histórico-política (1820-1940), „Historia Crítica” 56, 2015, s. 56; N. Simão Ferreira, O sindicalismo orgânico proposto pelo Integralismo Lusitano e o nacionalsindicalismo, w: Atas do I Congresso de História do Movimento Operário e dos Movimentos Sociais em Portugal, t. 7, red. A. Simões do Paço, C. Teixeira, P. Godinho, R. Varela, V. Borges Pereira, Lisboa 2016, s. 133. Najbardziej wpływowym twórcą ideologii portugalskiego nacjonalizmu integralnego był António Sardinha (1887-1925). Swój projekt polityczny najbardziej szczegółowo nakreślił on w pracy pt. $O$ Valor da Raça. Introdução a uma campanha nacional, Lisboa 1915. Za warunek ustanowienia mądrych metod pracy, dyscypliny, fachowości, autonomii grup pracowniczych i spójności społecznej uznawał przywrócenie średniowiecznego korporacjonizmu. Jego ideałem „prawdziwej Ojczyzny” była 
Twórca systemu korporacyjnego wprowadzonego w Portugalii w 1933 r. był António de Oliveira Salazar, pełniący od 1932 r. funkcję premiera rządu. Przekonywał on, że korporacyjna struktura społeczna będzie skutecznym środkiem zaradczym na kryzys demokracji (i szerzej: na powszechny kryzys współczesnego państwa), poddawał krytyce parlamentaryzm, odrzucał dominację partii w życiu politycznym (,,partiokrację"), w hierarchii wartości wyżej sytuował prawa życia społecznego niż wolności indywidualne. Krytykę demokracji łączył on z apologia reprezentacji politycznej opartej na organicznym prawie wyborczym. Wśród organizmów, których suma tworzy naród, wymieniał on rodziny, gminy, municypia, korporacje zawodowe. Zakładał, że korporacje będa miały nie tylko prerogatywy administracyjne na poziomie lokalnym i regionalnym, lecz także prawa polityczne, pozwalające im wpływać na politykę państwa ${ }^{11}$.

Dążąc do naświetlenia okoliczności ustanowienia systemu korporacyjnego jako zasadniczego ogniwa ustroju ekonomiczno-politycznego portugalskiego Nowego Państwa (1933-1974), warto oddać głos głównemu architektowi tego projektu. Argumenty uzasadniajace jego wprowadzenie Salazar przedstawił m.in. w zbiorze swych mów politycznych, opublikowanych w 1937 r. po francusku jako Une révolution dans la paix ${ }^{12}$.

Uzasadniając potrzebę ustanowienia nowych zasad ustrojowych, Salazar odwoływał się do tych uwarunkowań życia politycznego, które pojawiły się po ustanowieniu Republiki (1910), przede wszystkim do „chronicznego stanu wrzenia rewolucyjnego”, chaosu politycznego, społecznego, finansowego i gospodarczego, niestałości i słabości władz państwowych, dominacji interesów partyjnych nad społecznymi. Pisał:

byliśmy już zmęczeni ciagłymi walkami wewnętrznymi, zalegalizowana wojna domowa. Przyglądaliśmy się współzawodnictwu grup politycznych przy zdobywaniu władzy i jaskrawym przejawom partyjniactwa przy sprawowaniu rządów. [...] Z rozpaczą patrzyliśmy na zmienność rządów, które

„wiejska Ojczyzna” XIV stulecia, jak pisał bowiem, ,zamiast zbiorowiska panów i sług [...] mieliśmy wówczas [...] Ojczyznę opartą na wspólnotach agrarnych Rasy, z municypium jako prawnym i społecznym wyrazem braterstwa, które żyje z ziemi i nie uznaje innego szlachectwa niż to, które powstaje w wyniku selekcji przez pracę i odwagę"; tamże, s. 110.

${ }_{11}$ A.R. Amaro, $O$ modelo político administrativo do Estado Novo português. Corporativismo e representação política das autarquias (1936-1959), „Espacio Tiempo y Forma. Serie V. Historia Contemporánea” 27, 2015, s. 89.

${ }^{12} \mathrm{~W}$ niniejszym artykule opieram się na drugim wydaniu polskiego tłumaczenia tej pracy, opublikowanym pt. Rewolucja pokojowa, Warszawa 2013 (tłum. Z. Grabski). 
pożerały swych własnych ludzi, na ciagłe dymisje wciąż nowych ministrów, które uniemożliwiały wszelką pracę administracyjną i wprowadzenie w czyn jakiejkolwiek myśli politycznej ${ }^{13}$.

Przypominał, że wobec tych zjawisk ,ze wszystkich stron domagano się zespolonego wysiłku dla ocalenia narodu; wysiłku, który by zapewnił krajowi podstawowy warunek, umożliwiający pracę i pomyślność porządek"14.

Ocena Salazara politycznej i społecznej sytuacji w okresie Republiki nie była sformułowana wyłącznie po to, by propagandowo usprawiedliwić polityczne rozwiązania, za którymi się on opowiadał, co potwierdzaja opinie współczesnych historyków. Okres, który nastapił po rewolucji 1910 r., rzeczywiście cechował się olbrzymią niestabilnością społeczna i polityczna, był czasem wielu napięć, konfliktów i niepewności. Politykę wewnętrzną kraju destabilizowało rozproszenie sił politycznych, dokonujących nieustannie secesji i podziałów, organizujących się i reorganizujących w nowe partie i partyjki. Dewastowały ją także osobiste ambicje przywódców politycznych, związane często z ich skłonnością do korupcji, oszustw wyborczych i klientelizmu. Skutkiem politycznej niestabilności była niemożność wypracowania i wprowadzenia głębszych reform społecznych i gospodarczych. Zjawiskom tym towarzyszył kryzys finansowy państwa, drożyzna, represje policyjne oraz częste zmiany rządów i osób na wysokich stanowiskach państwowych. Do codzienności miast, zwłaszcza w latach 20., należała przemoc polityczna - zamachy stanu, zbrojne napaści na siedziby partii i czasopism, morderstwa i skrytobójstwa przywódców politycznych ${ }^{15}$. Robotnicy przemysłowi, nie dostrzegając rozwiązań problemów społeczno-ekonomicznych odziedziczonych przez Republikę po monarchii, angażowali się w zdominowany przez anarchosyndykalizm ruch strajkowy, coraz bardziej skłonny do szukania zbrojnych rozwiązań trudności. Czasy Republiki były „monotonna, szalona, prawie zawsze krwawą kroniką ciagłych rozczarowań i niekończących się majaczeń o coraz szybszym rytmie, kroniką postępującej degradacji ideału, wiary i nadziei w ustrój, który był, mimo wszystko, proklamowany, uznany i popierany z jednomyślnym i niemal mesjanistycznym entuzjazmem, jaki kiedykolwiek widziały epoki

13 Tamże, s. 92.

14 Tamże, s. 63.

${ }^{15}$ L. Salgado de Matos, A Primeira República Portuguesa entre a Instituição Estado e a Ordem Povo, „Historia Constitucional” 13, 2012, s. 618; J. Medina, A democracia frágil. A Primeira República Portuguesa (1910-1926), w: História de Portugal, red. J. Tengarrinha, São Paulo-Lisboa 2000, s. 308-309. 
naszej osiemsetletniej historii" - pisze José Medina ${ }^{16}$. Polityka republikańska została utożsamiona przez wszystkie grupy społeczne Portugalii z niekończącym się kryzysem. Wojskowy zamach stanu w maju 1926 r., a następnie ustanowienie dyktatury wojskowej większość społeczeństwa Portugalii przyjęła $\mathrm{z}$ entuzjazmem i nadziejami ${ }^{17}$.

Charakteryzując rozwiązania polityczne, jakie planował wprowadzić w kraju, Salazar oznajmiał: „jesteśmy przeciwnikami parlamentaryzmu, demokratyzmu, liberalizmu"18. Odrzucał wykreowane przez liberalizm polityczny pojęcie „obywatela”, które, według niego, definiowało go jako ,jednostkę oderwaną od rodziny, od klasy społecznej, od zawodu, od środowiska kulturalnego, od społeczności gospodarczej, do których należała"19. Jako elementarne jednostki życia społecznego (narodowego) Salazar przeciwstawiał mu „ugrupowania naturalne”. Pisał, że u podstaw społecznego bytowania „znajduje się rodzina, pierwsza komórka społeczna, zarodek parafii, gminy" ${ }^{20}$. Do naturalnych jednostek społecznych, które „reprezentuja prawdziwe i uzasadnione interesy życia zbiorowego" ${ }^{21}$, zaliczał także zrzeszenia kulturalne i gospodarcze oraz stowarzyszenia (związki, syndykaty) zawodowe robotników. Ustrojowym ideałem Salazara był więc naród zorganizowany w system korporacyjny, „według planu naturalnego, to jest, uwzględniając samorzutne ugrupowania ludzi do ich interesów lub zajęć" 22 .

Ustrój polityczny, który został wprowadzony w Portugalii konstytucją z 1933 r., przyjętą w powszechnym referendum, był nazywany przez Salazara dyktatura. Jej zaletę dostrzegał on m.in. w szybkości działania organów władzy w celu zapanowania nad chaosem. Był przekonany, że zapewni ona krajowi ład i stałość, poprawi warunki życia robotników, ponieważ, jak twierdził, dyktatury funkcjonuja „,bez uprzedzeń partyjnych i klasowych, w myśl wskazań porządku i dyscypliny i w oparciu o jedyne kryterium najwyższego dobra całego narodu"23. Dyktat miało sprawować państwo, które, jak przekonywał Salazar, powinno być silne, „aby móc opanować prądy rewolucyjne, zapewnić jedność narodowa, uzgodnić działalność wszystkich czynników”24.

${ }^{16}$ J. Medina, dz. cyt., s. 308.

17 A.H. de Oliveira Marques, Da Monarquia para A República, w: História de Portugal..., s. 297.

18 A. Salazar, dz. cyt., s. 26.

19 Tamże, s. 83.

20 Tamże, s. 84.

${ }_{21}$ Tamże.

22 Tamże, s. 202.

${ }^{23}$ Tamże, s. 68.

${ }^{24}$ Tamże, s. 109. 
Projekt nowego ustroju politycznego portugalskiego państwa zakładał także oparcie gospodarki na nowych zasadach. Niektórzy badacze tego okresu twierdzą wręcz, ,że to kryzys finansowy i gospodarczy dał życie salazaryzmowi” ${ }^{25}$ oraz że korporacyjna struktura Nowego Państwa miała charakter wybitnie ekonomiczny ${ }^{26}$. Podstawa nowej ekonomii miała być autonomia życia gospodarczego, niemniej Salazar rezerwował dla państwa prawo do interweniowania $\mathrm{w}$ nie w celu zapobiegania nadużyciom i chronienia interesów zbiorowych.

Projekt Salazara spotkał się z krytyką różnych opcji ideologicznych. Chociaż niektórzy krytycy prezentujaccy postawy nacjonalistyczne wyrażali swoją sympatię dla idei organicystycznych i korporacyjnych, to jednak nie potrafili sobie wyobrazić ustanowienia korporacyjnej struktury państwa wobec nieistnienia w Portugalii korporacji, które, po zadekretowaniu takiego porządku, należałoby w długotrwałym procesie tworzyć od początku. Inni krytycy projekt ten uznawali za niebezpieczna fantazję, dostrzegając, że chociaż portugalska rodzina, mająca być podstawą systemu społecznego i politycznego, cechuje się wielkimi cnotami moralnymi, to poziom jej obywatelskiej świadomości jest bardzo niski. $\mathrm{W}$ odniesieniu do zapowiedzi ustanowienia w parlamencie izby korporacyjnej, wobec skromnego poziomu tej świadomości oraz braku umiejętności specjalistycznych, potrzebnych do sprawowania władzy (nie wspominajac o bardzo wysokim poziomie analfabetyzmu, zwłaszcza $\mathrm{w}$ środowiskach wiejskich), byli oni skłonni przyznać jej charakter jedynie doradczy (w stosunku do Zgromadzenia Narodowego i rządu), a nie ustawodawczy. Rezerwę wobec planów Salazara zachowali także integraliści; Junta Central do Integralismo Lusitano odmówiła ich poparcia. Krytyki planu Salazara niekiedy szły tak daleko, że np. Alfredo Pimenta, lider nacjonalistycznej Ação Realista, będącej zradykalizowana emanacją ideologii Integralismo Lusitano, głosił, że preferuje republikańską konstytucję z 1911 r. niż ustanowienie korporacyjnej reprezentacji politycznej ${ }^{27}$. Przeciwnikami korporacjonizmu byli republikanie, którzy za najważniejszą wartość życia społecznego uznawali suwerenność jednostek i społeczeństwa. Podobne stanowisko zajmowali liderzy

${ }^{25}$ L. Reis Torgal, „Crise” e „crises” no discurso de Salazar, „Estudos do Século XX” 10, 2010, s. 409.

${ }_{26}$ Á. Garrido, O Estado Novo português e a institucionalização da „economia nacional corporativa”, „Estudos do Século XX” 10, 2010, s. 305.

${ }^{27} \mathrm{P}$. Borges Santos, O modelo político do estado autoritário português. A ideia corporativa na constitucionalização do regime (1931-1933), „Espacio Tiempo y Forma. Serie. Historia Contemporánea" 27, 2015, s. 70-71; A. Wielomski, Faszyści portugalscy wobec dyktatury Antonia de Oliveiry Salazara, w: Franco i Salazar..., s. 239-240. 
„starych” związków zawodowych. Podporządkowanie interesom narodowym i współpraca między klasami społecznymi były nie do pomyślenia zwłaszcza dla tych związkowców, którzy podzielali klasową koncepcję społeczeństwa ${ }^{28}$. I mimo że przynajmniej niektórzy z nich mogli, chociaż niełatwo, zaakceptować współpracę z państwem (widzianym niekiedy jako instytucja kapitalistyczna, która usiłuje narzucić społeczeństwu burżuazyjny porządek), to jako bardzo problematyczną postrzegali oni współpracę z pracodawcami (kapitałem). Nieprzekraczalną granicę ich kompromisu wyznaczała rezygnacja z walki klasowej. Jednak postawa „starych” związkowców nie miała większego znaczenia wobec osłabienia ich roli przez ograniczenie działalności zrzeszeniowej po zamachu stanu i wprowadzeniu dyktatury w 1926 r. Wówczas została także zawieszona działalność partii politycznych ${ }^{29}$. Oba te fakty uczyniły portugalska scenę polityczna terenem gotowym na przeprowadzenie - jak to określił Salazar - „kilku eksperymentów politycznych, które przyszłość zatwierdzi albo odrzuci, zmieni albo poprawi”30.

\section{Ogniwa i instytucje portugalskiego systemu korporacyjnego}

Podstawę prawną systemu korporacyjnego w Nowym Państwie stanowiła promulgowana w 1933 r. konstytucja (Constituição Política da República Portuguesa). W jej artykule 5. stwierdzano, że „państwo portugalskie jest Republika jednolitą i korporacyjna". Odniesienie do tego systemu w konstytucji było jednak mało konkretne. W 15. artykule konstytucji zapowiadano, że zasady jego funkcjonowania zostana uregulowane oddzielnym aktem prawnym. Rolę „wielkiej karty portugalskiego korporacjonizmu" odegrał przyjęty tego samego roku Estatuto do Trabalho Nacional (Narodowy Statut Pracy) ${ }^{31}$. Jako fundamentalne

${ }^{28}$ F. Patriarca, A institucionalização corporativa - das associações de classe aos sindicatos nacionais (1933), „Análise Social” 26, 1991, nr 110, s. 50.

${ }^{29}$ Jedyna partia, która funkcjonowała w okresie Nowego Państwa, była União Nacional (w 1973 r. zmieniono jej nazwę na Acção Nacional Popular) z Salazarem jako jej liderem. Jej manifest polityczny ogłoszono 30 VII 1930 r. Z założenia nie miała być partią polityczna, lecz „platformą współpracy, nieodzowną dla nowej polityki, dla nowej administracji i nowej gospodarki”; A. Salazar, dz. cyt., s. 91.

30 Tamże, s. 110.

${ }^{31}$ Do czasu ogłoszenia w 1933 r. Estatuto do Trabalho Nacional w Portugalii obowiązywało prawo pracy regulowane ustawami z 1891 i 1924 r. Po ogłoszeniu Estatuto ustawa z 1891 r., wcześniej krytykowana przez związkowców jako opresyjna wobec robotników, wydała się im gwarancją wolności; F. Patriarca, dz. cyt., s. 41-42. 
zasady porządku korporacyjnego oba te dokumenty wskazywały podporządkowanie interesów indywidualnych interesom narodowym, prawo państwa do regulowania życia gospodarczego i społecznego oraz zasadę współpracy ekonomicznej i społecznej przedsiębiorców i pracowników (pracy i kapitału) ${ }^{32}$. Z doktrynalnego punktu widzenia organizacje korporacyjne miały spełniać polityczną funkcję reprezentatywną oraz regulacji ekonomicznej.

System korporacyjny stanowił zhierarchizowaną i kontrolowaną przez państwo sieć instytucji z wyróżnionymi trzema poziomami organizacyjnymi. W 41. artykule Estatuto do Trabalho Nacional stwierdzano: „Syndykaty Narodowe zatrudnionych i robotników oraz Gildie (Grémios) tworzone przez jednostki pracodawców stanowią element podstawowy organizacji korporacyjnej i grupuja się w federacje oraz unie, będące elementem pośrednim korporacji, która jest najwyższą instytucją tej struktury". Zgodnie z tym samym artykułem federacje, będące stowarzyszeniami związków zawodowych i gremiów „identycznych”, mogły mieć charakter regionalny i krajowy (narodowy). Artykuł 42. precyzował znaczenie określenia ,identyczny”, wskazujacc, że chodzi o „kategorię pracodawców i zatrudnionych czy zarabiających w tej samej dziedzinie handlu, przemysłu czy zawodu" - niezależnie od tego, czy są oni członkami związków i gildii, czy też nie.

Kolejne postanowienia dotyczace systemu korporacyjnego zawarto w pięciu dekretach uchwalonych 23 IX 1933 r. ${ }^{33}$ Artykuł 5. dekretu ustawodawczego nr 23049 precyzował, że powoływanie gildii należy do inicjatywy ministrów oraz że podlegają one bezpośrednio Sub-Secretariado das Corporações e Previdência Social (Podsekretariatowi Korporacji i Ubezpieczeń Społecznych, SCPS). Dekretem nr 23053 powołano Instituto Nacional do Trabalho e Previdência (Narodowy Instytut Pracy i Ubezpieczeń Społecznych, INTP), stwierdzając, że ma on na celu „zapewnienie realizacji praw ochrony pracy i innych praw o charakterze społecznym, integrując pracowników i pozostałe elementy produkcji w organizacji korporacyjnej przewidzianej w Narodowym Statucie Pracy”. INTP miał działać pod nadzorem SCPS. Artykuł 5. tego samego dekretu określał jego zadania: „monitorowanie problemów związanych

${ }^{32}$ L. Aboim Pires, Corporativismo e proteção laboral no Estado Novo português. $O$ caso dos acidentes de trabalho e doenças profissionais (1936-1974), „Oficina do Historiador" 9, 2016, nr 2, s. 83; H.M. Marques, $O$ movimento sindical durante o Estado Novo. Estado actual da investigação, „Revista da Faculdade de Letras do Porto: História. III Série" 8, 2007, s. 301.

${ }_{33}$ Były to dekrety o numerach 23 049, 23 050, 23 051, 23 052, 23 053; zob. „Diário do Governo" 217, 23 IX 1933. 
z praca i ubezpieczeniami społecznymi oraz odpowiadajacych im rozwiązań, wspieranie organizacji korporacyjnej i kierowanie nią oraz propagowanie ducha nowego porządku społecznego".

Dekret nr 23051 postanawiał utworzenie we wszystkich parafiach wiejskich ${ }^{34}$ „organizmów współpracy społecznej” pod nazwą casas do povo (domów ludowych), pozostawiając inicjatywę w tym zakresie zainteresowanym, radom parafii, innym władzom administracyjnym, a także SCPS. Stanowił on także, że w jednej parafii może być tylko jeden dom ludowy oraz wskazywał zakres jego kompetencji: „działania mające na celu zapewnienie jego członkom opieki i pomocy w wypadku choroby, bezrobocia, niezdolności do pracy i starości”, „nauczanie dorosłych i dzieci, sport, rozrywkę i kino edukacyjne”, „współdziałanie w ramach prac wspólnej użyteczności (obras de utilidade comun), komunikacji, dostaw wody i higieny publicznej”. Dekret nr 28859 z 18 VII 1938 r. określał ponadto, że zadaniem domów ludowych jest zawodowa reprezentacja wszystkich pracowników będących ich członkami, obrona ich interesów moralnych, społecznych i ekonomicznych w radach municypalnych.

Domy ludowe były pierwszymi organizmami korporacyjnymi poziomu podstawowego, jakie zostały ustanowione po promulgowaniu dekretów ustanawiajacych portugalski korporacjonizm. Ich członkami mogli być mężczyźni powyżej 18. roku życia, będący głowami rodzin oraz ci właściciele ziemscy, których stan posiadania nie odbiegał znacznie od stanu posiadania robotników rolnych. Wyróżniano także kategorię członków-protektorów czy „dobroczyńców” (sócios protetores), którzy mogli dobrowolnie wspierać te instytucje, choćby od czasu do czasu i jakakolwiek kwota. Wyodrębniona kategorię stanowili „protektorzy naturalni” (protetores natos), do której zaliczano wszystkich naczelników rodzin będacych właścicielami ziemskimi w danej gminie; byli oni zobowiązani do wpłacania co miesiac określonej kwoty na rzecz domu ludowego.

Dekret nr 23051 zabraniał tworzenia organizacji o podobnym charakterze w tych gminach, w których funkcjonowały domy ludowe. Jeżeli takie już istniały ${ }^{35}$, były prawnie uznawane bądź rozwiązywano je lub obniżano rangę ich funkcji. Chodziło przede wszystkim o wyeliminowanie z życia społecznego i politycznego rolniczych związków zawodowych.

${ }^{34}$ Parafia jest w Portugalii najmniejszą jednostką podziału administracyjnego kraju.

${ }^{35}$ Domy ludowe od końca XIX w. były tworzone w różnych krajach, zwłaszcza w Anglii, Danii, Hiszpanii, Rosji, Szwecji, Turcji i Włoszech. Pełniły one głównie funkcje ośrodków kultury, były wyposażone w sale widowiskowe i wystawiennicze, biblioteki i czytelnie. 
W epoce, w której nad Zachodem unosiło się „czerwone zagrożenie”, Nowe Państwo starało się odsunać ludność wiejską od „walki klas” czy „destrukcyjnych idei”, zakazując tworzenia związków zawodowych i innych organizacji robotniczych. Ponadto, pod tym czy innym pretekstem, dążyło ono także do likwidacji innych organizacji podejrzewanych o mobilizowanie społeczeństwa obywatelskiego i zdolnych do konkurowania w obszarze opieki społecznej, edukacji i organizacji czasu wolnego, jakie znajdowały się w zakresie funkcjonowania tych organizmów korporacyjnych ${ }^{36}$.

Niektórzy autorzy, biorac pod uwage ten fakt, jak również priorytetowe traktowanie przez Nowe Państwo tworzenia domów ludowych $\mathrm{w}$ tych regionach, gdzie dominowała wielka własność ziemska, skłaniają się ku opinii, że ta forma korporacjonizmu miała na celu także utrzymanie latyfundiów przez arbitralne narzucanie robotnikom rolnym warunków pracy i płacy. W ten sposób państwo gwarantowało latyfundystom tanią siłę robocza, ale także miało możliwość sprawowania politycznej kontroli nad ludnością wiejską i społecznym pokojem $\mathrm{w}$ tych regionach, które w czasach I Republiki były areną ożywienia społecznego i politycznego ${ }^{37}$.

Domy ludowe były wprawdzie instytucjami, ogniwami systemu korporacyjnego (,organizmami współpracy społecznej”), jednak nazwa tych organizmów prawnych ma swoje uzasadnienie w najbardziej dosłownych przejawach ich bytowania, jakimi były zwykle dość okazałe budynki użyteczności publicznej, przystosowane do wyznaczonych im funkcji. W latach 1946-1971 władze centralne publikowały miesięcznik „Casas do Povo", którego każdy numer zawierał instrukcje i sugestie dotyczące zasad funkcjonowania i form aktywności tych instytucji, architektury domów ludowych i ich niezbędnego wyposażenia. Był on także uprzywilejowanym medium propagowania wśród ludności wiejskiej ideologii Nowego Państwa.

Tworzenie sieci domów ludowych było powolne i nie zdołało objąć wszystkich $\operatorname{gmin}^{38}$. Gęstość tej sieci była odmienna w różnych regionach kraju. Podlegały one kontroli INTP. Jego delegatury były odpowiedzialne za prawidłowy wybór organów kierowniczych domów ludowych, kontrolowały ich aktywność administracyjną i prawidłowość wydatków.

${ }_{36}$ D. Freire, Estado Corporativo em acção: sociedade rural e construção da rede de Casas do Povo, w: Corporativismo, Fascismos, Estado Novo, red. F. Rosas, Á. Garrido, Coimbra 2012, s. 277.

37 Tamże, s. 279.

${ }^{38}$ D. Freire, N.E. Ferreira, A.M. Rodrigues, Corporativismo e Estado Novo. Contributo para um roteiro de arquivos das instituições corporativas (1933-1974), Lisboa 2014, s. 16. 
Najbardziej dynamicznie sieć domów ludowych rozwijała się w Portugalii od $1933 \mathrm{r}$. do drugiej połowy lat 50. Od połowy lat 60. były one tworzone także na „terytoriach zamorskich” (w koloniach) Portugalii.

Domy rybackie (casas dos pescadores), jako kolejna struktura podstawowa systemu korporacyjnego (prawnie ustanowiona ustawa nr 1953 z 1937 r.; zasady funkcjonowania domów rybackich określił dekret $\mathrm{nr} 27978 \mathrm{z}$ tego samego roku $^{39}$ ), zakładane z inicjatywy zainteresowanych bądź przez lokalna administrację, zrzeszały rybaków, armatorów i właścicieli łodzi; przynależność tych ostatnich do tej struktury była obowiązkowa. Były one zakładane z intencja utworzenia instytucji, które miały zapewniać ich członkom reprezentację zawodowa, ubezpieczenie od wypadków oraz wsparcie materialne, moralne i religijne, a także kultywowanie lokalnych tradycji, związanych z cnotami ludzi morza. W 1974 r. istniało 28 takich domów, 23 z nich obejmowały swym zasięgiem wszystkie tereny nadmorskie kraju, natomiast 5 utworzono na wyspach należacych do Portugalii. Poza sprawami związanymi z regulacja zasad pracy podejmowały one inicjatywy edukacyjne (niektóre tak ważne jak szkoły kształcące w zawodach związanych z rybołówstwem), kulturalne i sportowe. Domy rybackie - jako jedyne w systemie korporacyjnym Nowego Państwa - długo, bo aż do 1968 r., nie miały swojego walnego zgromadzenia, jak również pochodzącego $\mathrm{z}$ wyboru zarządu (był on mianowany przez rząd), były zatem pozbawione jakichkolwiek znaczących form samorządności. „W wielu społecznościach rybackich te małe instytucje korporacyjne były postrzegane jedynie jako miejsca odpoczynku i opieki, zwłaszcza te, które posiadały gabinet lekarski”"

Po rewolucji 1974 r., wraz z likwidacja systemu korporacyjnego w Portugalii, domy rybackie przestały pełnić funkcję reprezentacji zawodowej rybaków. Niekiedy gorliwość nowo ustanowionych władz w likwidacji systemu korporacyjnego posuwała się zbyt daleko, jak w wypadku domów rybackich, wraz z pozbawieniem ich funkcji reprezentacji zawodowej zlikwidowano bowiem także dobrze rozwiniętą sieć szkół rybackich, będacych jednym z najlepszych efektów ich działalności.

${ }^{39}$ Dekret nr 37751 z 4 II 1950 r. na nowo określał zasady funkcjonowania domów rybackich, jednak nie wprowadzał w tym zakresie istotnych zmian. Natomiast dekret nr 48506 z 30 VII 1968 r. takie zmiany ustanawiał; dotyczyły one powołania różnych form samorządu tych instytucji, m.in. walnego zgromadzenia, zarządu i rady konsultacyjnej.

${ }^{40}$ Á. Garrido, „A terra e o mar não se sindicalizam!”. As Casas dos Pescadores no sistema corporativo do Estado Novo português (1933-1968), w: Tra due crisi. Urbanizzazione, mutamenti sociali e cultura di massa tra gli anni Trenta e gli anni Settanta, red. M. Pasetti, Bologna 2013, s. 97. 
Pracownicy przemysłu i handlu mieli być zorganizowani w syndykatach narodowych (ogólnokrajowych związkach zawodowych). One także należały do kategorii instytucji korporacyjnych o charakterze podstawowym. Chociaż były tworzone z inicjatywy zainteresowanych, to podlegały kontroli władz państwowych, co odróżniało je od związków zawodowych istniejacych w Portugalii przed wprowadzeniem systemu korporacyjnego. Przynależność do nich przed II wojną światową była dobrowolna, jednak później od czasu do czasu, tzn. gdy państwo uznało za stosowne, bywała już obligatoryjna.

„Reprezentanci federacji i unii "syndykatów narodowych« i "gildii« mieli skupiać się w najwyższym organizmie: korporacji, której główna funkcją miało być firmowanie kontraktu zbiorowego, lecz także miała być ona odpowiedzialna za regulowanie i porządkowanie życia gospodarczego"41. Ważną funkcją korporacji miało być reprezentowanie interesów skupionych $\mathrm{w}$ nich pracowników, poprzez negocjowanie zbiorowych umów o pracę. Ten aspekt funkcjonowania korporacji uznawano za najistotniejsza formę jej działalności. Zgodnie z prawem podjęcie tego rodzaju aktywności zależało od wolnej inicjatywy obu stron (tzn. pracodawców i pracowników). Przyjęte ustalenia, po ich podpisaniu przez obie strony, miały zastosowanie ogólne, tzn. obligowały wszystkich pracodawców i pracowników tej samej gałęzi przemysłu, handlu czy zawodu ${ }^{42}$. Obowiazywały one wyłącznie po ich zaaprobowaniu przez organy państwa i w istocie rzeczy to ono, poprzez delegatów i asystentów INTP, prowadziło negocjacje umów i w praktyce jednostronnie określało warunki kontraktów. Syndykaty miały więc ograniczoną autonomię, były kontrolowane przez państwo za pośrednictwem jego instytucji - INTP i SCPS. Na mocy Estatuto do Trabalho Nacional państwo było upoważnione do kontrolowania działalności związków zawodowych, interweniowania w sytuacjach, gdy nie była ona znaczacca, aprobowania ich statutów (przez SCPS) czy ich rozwiazywania. Prawo homologacji statutów było używane po to, by dopasować krajowe zwiazki zawodowe do modelu ideologicznego Nowego Państwa ${ }^{43}$. Kontrola działalności korporacyjnej i związkowej była tak daleko posunięta, że w 1943 r. zabroniono publikowania w prasie wydawanej przez te organizmy materiałów o treści społecznej bez zgody delegata rządu bądź przedstawiciela INTP.

Gildie nie były poddane takiej kontroli, ciesząc się większą swobodą działań w interesie swoich członków. Przynależność do gildii była

\footnotetext{
${ }^{41}$ F. Bernal García, dz. cyt., s. 60.

${ }^{42}$ F. Patriarca, dz. cyt., s. 30.

${ }^{43}$ H.M. Marques, dz. cyt., s. 302.
} 
obowiązkowa. Były one ustanawiane dekretami władz państwowych, w szczególności ministrów rolnictwa, przemysłu, handlu i komunikacji, natomiast ich członkami były przedsiębiorstwa, stowarzyszenia i firmy. Gildie miały zasięg regionalny i krajowy, emitowały regulacje gospodarcze dotyczące parametrów produkcji i dystrybucji towarów oraz świadczenia usług, o obligatoryjnym trybie zastosowania. Możliwe było tworzenie gildii dobrowolnych. Inicjatywa ich powoływania należała do zainteresowanych, jednak wymagały one zatwierdzenia przez władze publiczne. Zrzeszały one organizmy o charakterze podobnym jak te gildie, do których przynależność była obowiązkowa i nie mogły być utworzone w tych sektorach, w których istniała już gildia obligatoryjna.

Jedna $\mathrm{z}$ odmian organizacji korporacyjnej poziomu podstawowego były gildie ziemiańskie (grémios da lavoura), zrzeszajace właścicieli ziemskich. Przynależność do ustanowionej na danym terytorium tego rodzaju gildii była dla nich obowiązkowa. Zadaniem tych gildii było promowanie aktywności rolniczej swych członków m.in. poprzez hurtowy zakup środków produkcji rolniczej oraz negocjowanie kontraktów z bankami i kompaniami ubezpieczeniowymi. Ułatwiały one także wytwórcom produktów rolniczych wejście na rynek.

Organizacja systemu gildii sektora rolniczego dokonała się w dwóch fazach. Pierwsza rozpoczęła się w 1933 r. i dotyczyła powołania gildii, do których przynależność była obowiązkowa. Obejmowały one tylko te sektory produkcji rolnej, których rozwojem i protekcją było zainteresowane państwo (sadownictwo, uprawa pszenicy i produkcja wina). W drugiej kolejności, od połowy lat 30., powstawały korporacje dobrowolne gildie ziemiańskie i „organy koordynacji gospodarczej” (organismos de coordenação económica). Chociaż ich tworzenie nie było obligatoryjne, to po ich założeniu wszyscy producenci rolniczy na danym terytorium byli zobowiązani należeć do nich. Fakt ten oraz to, że rząd mógł je utworzyć, gdy zainteresowane strony tego nie zrobiły i stały się one niezbędne dla ochrony gospodarki narodowej, sprawił, że w praktyce stały się one obowiazkowe ${ }^{44}$. Łaczyły się one w federacje regionalne i do $1974 \mathrm{r}$. stanowiły podstawę organizacji korporacyjnej związanej z rolnictwem.

Organizmami o charakterze ogólnokrajowym były korporacje. Prawne podstawy tych instytucji zostały ostatecznie ogłoszone w $1956 \mathrm{r}$. Ustanowiono wówczas jedenaście korporacji, będących zrzeszeniami federacji i unii. Były to „uprzywilejowane organy konsultacji rządowych” ${ }^{4}$.

${ }^{44}$ O. Simões, A economia das instituições agrícolas em Portugal. Contributo para um quadro conceptual de análise, „Análise Social” 39, 2004, nr 172, s. 608.

${ }^{45}$ D. Freire, N.E. Ferreira, A.M. Rodrigues, dz. cyt., s. 17. 
Zostały także powołane instytucje mające na celu koordynację pracy wskazanych organizmów. Przykładem może być powołana w $1937 \mathrm{r}$. Junta Central das Casas dos Pescadores (Centralny Zarząd Domów Rybackich). Była ona odpowiedzialna za administrowanie wspólnym funduszem finansowego wsparcia pracowników morza, organizacją sprzedaży połowów, zasiłkami rodzinnymi, dotacjami na remonty i budowę mieszkań. W 1945 r. został utworzony wspomniany Centralny Zarząd Domów Ludowych, mający podobne zadania. Rozwiązano ja w 1985 r.

Pierwotnie system korporacyjny był koordynowany przez INTP, podlegający bezpośrednio premierowi. Następnie funkcję tę miało spełniać utworzone w 1950 r. Ministerstwo Korporacji i Ubezpieczeń Społecznych ${ }^{46}$. Ponadto $\mathrm{w}$ parlamencie utworzono izbę korporacyjną (Câmara Corporativa), złożoną z przedstawicieli korporacji, niemająca jednak uprawnień legislacyjnych.

Tworzenie systemu korporacyjnego w Portugalii zakończono w drugiej połowie lat 50. Opóźnienie to oficjalnie tłumaczono chęcią uniknięcia budowania go „od góry” i czasem potrzebnym syndykatom i gildiom na ich pełny rozwój, zanim zaczna one realnie funkcjonować. System korporacyjny przez cały okres trwania reżimu podlegał przemodelowaniom. Mimo znaczaccych przemian, jakie zaszły w wewnętrznej polityce Portugalii po odsunięciu się od władzy Salazara (1968) i objęciu funkcji premiera przez Marcello Caetano, korporacjonizm zachował w Nowym Państwie doktrynalną i organizacyjną doniosłośćc ${ }^{47}$. Wprawdzie zyskał on bardziej zliberalizowana postać, nadal jednak jakikolwiek ruch w kierunku politycznej demokracji był wykluczony (jak określał to sam Caetano, jego polityka była polityką odnowy i kontynuacji polityki Salazara; taki właśnie tytuł nosi zbiór jego mów politycznych: Renovação na Continuidade ${ }^{48}$ ). W końcu lat 60 . robotnicy wystapili z żądaniami poprawy warunków pracy i życia. Władze państwowe dostrzegły wówczas potrzebę wprowadzenia większej spójności między formą życia

${ }^{46}$ Niektórzy autorzy w utworzeniu tego ministerstwa dostrzegają początek odwrotu od korporacyjnej organizacji społeczeństwa portugalskiego w kierunku Welfare State; zob. M. de Lucena, Previdência Social, w: Dicionário da História de Portugal, t. 9, red. A. de Barreto, M.F. Mónica, Porto 1999, s. 161.

${ }^{47}$ Caetano dostrzegał potrzebę zmian polityki Nowego Państwa, jednak ich granicę wyznaczało trwanie jego struktury korporacyjnej. Głosił on, że mimo zmian polityki Nowego Państwa w kierunku państwa socjalnego (Estado Social) i opiekuńczego (Estado Providência), korporacjonizm jako organizacja życia społecznego i gospodarczego oraz jako doktryna polityczna pozostanie elementem niezmiennym; zob. M. Caetano, Estado Social. Excertos de discursos proferidos pelo Presidente do Conselho de Ministros Prof. Doutor Marcello Caetano, Lisboa 1970, s. 19.

${ }^{48}$ Zob. tenże, Renovação na Continuidade, Lisboa 1971. 
politycznego i modelem rozwoju ekonomicznego i społecznego, co Caetano wyraził w haśle przejścia od Nowego Państwa do państwa socjalnego (Estado Social) ${ }^{49}$. Konkretyzowało się ono w formie ostrożnego politycznego uznania opozycji oraz znacznego poszerzenia systemu ubezpieczeń społecznych. W 1969 r. nastapiła także pewna liberalizacja prawa regulującego funkcjonowanie zwiazków zawodowych. Uzyskały one wówczas większą autonomię, wybrane przez ich członków kierownictwo nie musiało być już zatwierdzane przez ministra, który jednak zachował prawo do jego zawieszenia i odwołania. W 1971 r., wobec wzrostu aktywności i radykalizacji związków zawodowych, które wymykały się spod kontroli państwa, oraz wielkiej fali strajków, pod wpływem radykalnego skrzydła jego formacji politycznej Caetano przywrócił wypróbowane zasady życia politycznego ustanowione przez Salazara.

\section{Stosunek do systemu korporacyjnego portugalskich środowisk społecznych i zawodowych}

Dawne związki zawodowe oceniły system korporacyjny jako ograniczajacy prawa pracownicze, sprowadzajacy pracowników do poniżającej roli wasali państwa, wymagający od nich ślepego posłuszeństwa, poddajacy ich jego kontroli i interesom oraz sprzeczny z rzeczywistymi interesami związkowymi ${ }^{50}$. Tak je postrzegali także liderzy działającej w podziemiu Partido Comunista Português (PCP). Początkowo całkowicie odrzucali oni system korporacyjny, jednak dość szybko zmienili swoją postawę. Od 1935 r. PCP podejmowała działania mające na celu wywieranie ideologicznego wpływu na robotników skupionych w syndykatach działajacych w legalnej strukturze korporacyjnej Nowego Państwa, a nawet zachęcała ich do wstępowania do związków zawodowych i regularnego opłacania składek, by za pośrednictwem swoich zwolenników wywierać wpływ na wybór odpowiednich osób do władz syndykatów czy organizować nacisk na nie. Skuteczność tej kampanii była jednak niewielka, ponieważ robotnicy zachowywali sceptyczny dystans

${ }^{49}$ F. Patriarca, Continuidade e ruptura. As primeiras leis sociais de Marcello Caetano, w: Itinerários. A investigação nos 25 anos do ICS, red. M. Villaverde Cabral, Lisboa 2008, s. 136.

${ }^{50}$ Określenie portugalskiego państwa „nowym” odnosi się do jego „niepolitycznej”, w intencji jego twórców, istoty, wiążących pojęcie polityki z liberalnym parlamentaryzmem i systemem politycznym opartym na konkurencji partii politycznych o władzę; zob. L. Reis Torgal, dz. cyt., s. 403; tenże, O conceito de „Estado social” na propaganda do Estado Novo, w: A cultura do poder. A propaganda nos estados autoritários, red. A. Pena-Rodríguez, H. Paulo, Coimbra 2016, s. 40. 
wobec działalności związkowej, podobnie zresztą jak spora część członków partii, którzy ponadto uznawali za upokarzające odgrywanie roli „konia trojańskiego”, rozsadzającego od wewnątrz układ korporacyjny. Państwo było świadome tych dążeń komunistów, dlatego poddawało ono działalność związkową stałej kontroli, przesuwało terminy wyborów kierownictwa zwiazków, unieważniało je bądź dymisjonowało wybrane zarządy, wprowadzając $w$ ich miejsce zaufanych ludzi. Niemniej niekiedy, zwłaszcza w latach 40., PCP udawało się odnieść sukcesy w wyborach do władz zwiazkowych. Były to krótkie okresy triumfu, państwo szybko bowiem przywracało porządek zgodny z jego własną wizją polityczną (np. przez odmowę zatwierdzenia wyniku wyborów).

Portugalskie środowiska katolickie wyrażały entuzjazm wobec systemu korporacyjnego tylko na etapie projektowania konstytucji oraz w początkowej fazie jego funkcjonowania. Zdawało się im wówczas, że nowy ustrój zrealizuje ich religijne i społeczne aspiracje. Po II wojnie światowej w ich łonie zaczęły się ujawniać, obejmując coraz szersze kręgi, postawy krytyczne zarówno wobec systemu korporacyjnego, jak i samego reżimu ${ }^{51}$ (niezmiennie wierna Salazarowi pozostawała natomiast hierarchia portugalskiego Kościoła). Katoliccy krytycy systemu korporacyjnego najczęściej byli związani z założoną w 1933 r. Acção Católica Portuguesa (ACP), organizacja społeczno-religijna, której celem było upowszechnianie zasad katolickich w życiu indywidualnym, rodzinnym i społecznym. Mimo że reżim w swojej propagandzie zdawał się być we wszystkim zgodny z nauczaniem Kościoła, to jednak w praktyce, dążąc do ideału politycznej homogeniczności, skrupulatnie rozgraniczał sfery własnej polityki i polityki Kościoła ${ }^{52}$. Salazar „oczekiwał od organizmów Akcji Katolickiej tylko »apostolatu« czy "wychowania duchowego«, a nie jakiejkolwiek formy interwencjonizmu społecznego czy działalności mającej na celu reprezentację i obronę interesów (do tych celów została powołana organizacja korporacyjna)"53.

${ }^{51}$ M.I. Rezola, Católicos, operários e sindicatos, „Lusitania Sacra” 6, 1994, s. 118.

${ }^{52}$ Mimo wspólnego języka katolickich zwolenników korporatywizmu i korporacyjnej ideologii Nowego Państwa istniały między tymi koncepcjami głębokie rozbieżności. Katolicy akcentowali zwłaszcza zasady autonomii grup społecznych, pomocniczości oraz wolności stowarzyszania, natomiast polityka Nowego Państwa była daleka od respektowania tych zasad. Salazar w swoich uzasadnieniach wprowadzenia systemu korporacyjnego nie odwoływał się do encyklik papieskich i raczej nie stanowiły one źródła inspiracji jego idei politycznych, społecznych czy ekonomicznych.

53 J. Barreto, Comunistas, católicos e os sindicatos sob Salazar, „Análise Social” 29, 1994, nr 125-126, s. 299; S. Duarte, A Liga Operária Católica: em defesa da concepção corporativa da doutrina social da Igreja (1949-1974), „Lusitania Sacra” 19-20, 2007-2008, s. 196. 
W istocie, ponieważ utworzenie katolickich związków zawodowych (tak samo jak i innych, które nie mieściły się w wyznaczonej prawem strukturze korporacyjnej Nowego Państwa) było niemożliwe, katolicy usiłowali wprowadzić do portugalskiego korporacjonizmu chrześcijańskiego ducha (,schrystianizować” go). Nie mniej ważne było dla nich praktyczne respektowanie prawa zatrudnionych do określonej w umowach zbiorowych liczby godzin pracy, minimalnej płacy, jej warunków, opieki medycznej, zasiłków macierzyńskich czy prawa do odpoczynku, naruszanych przez pracodawców i niewywołujących reakcji korporacyjnych instytucji państwa. Kiedy okazało się, że ich wysiłki, mające na celu obronę materialnych, intelektualnych i duchowych interesów pracowników, nie są przez państwo tolerowane, na przełomie lat 40. i 50. wycofali oni swe poparcie dla korporacyjnej organizacji portugalskiego życia. Podejmowana przez kręgi upolitycznionych katolików krytyka tego systemu (i implikowana przez nią krytyka ustroju Nowego Państwa) od końca lat 30. przybierała na sile, a w ostatnich latach rzadów Salazara była bliska krytyce podejmowanej przez członków partii komunistycznej. Z tego powodu bywali oni nazywani przez reżim i kościelną hierarchię „,komunistami Kościoła”. Określano ich także epitetem katolików „postępowych”, również w ten sposób insynuując ich ideowe pokrewieństwo $\mathrm{z}$ komunizmem ${ }^{54}$. Ze względu na tę postawę, ich publikacje i prasa zostały uznane przez reżim za zagrażające „duszy narodu", godności robotników i deformujące prawdę. Podlegały one państwowej cenzurze, stosowano wobec nich szykany finansowe oraz zabraniano ich publikowania.

Wielu przedsiębiorców także odnosiło się z rezerwą do korporacjonizmu, preferując instytucje utworzone w XIX stuleciu, w czasach monarchii liberalnej, które w okresie Nowego Państwa funkcjonowały poza marginesem systemu korporacyjnego. „Nic nie świadczy o tym, by był on pożądany przez kogokolwiek, kto był bezpośrednio związany z gospodarka, zarówno przez pracodawców, jak i pracowników [...] był on ani mniej ani bardziej »obcy" niż porządek liberalny, który miał zastapić. Niezależne związki zawodowe spoglądały na niego z ogromną nieufnością [...]; pracodawcy także byli nieufni, widząc w nim odmianę »białego bolszewizmu", mająca na celu ograniczenie ich prerogatyw" 55 .

Mimo wysiłków portugalskich ekonomistów okresu Nowego Państwa (najwybitniejsi z nich to João Pinto da Costa Leite oraz José Joaquim Teixeira Ribeiro), zmierzających do zbudowania teorii ekonomicznej,

\footnotetext{
54 J. Barreto, dz. cyt., s. 296.

${ }^{55}$ F. Ribeiro de Meneses, Salazar. A Political Biography, New York 2009, s. 88.
} 
„która uniknie zła socjalistycznej ekonomii planowej (braku wolności indywidualnej), jak i społecznych błędów tkwiących w systemie liberalnego kapitalizmu (skrajna konkurencja, nędza, marnotrawstwo surowców)" ${ }^{56}$, teoria ekonomii korporacyjnej nie została wypracowana. Kwestionowali oni przede wszystkim tezę o spontanicznej regulacji stosunków ekonomicznych, głosili apologię ścisłej tożsamości interesów jednostki i państwa, zakładając, że „zaspokojenie przez jednostkę własnego interesu może dokonać się jedynie przez realizację interesu narodowego" ${ }^{57}$. Ich ideałem (celem możliwym do osiagnięcia w przyszłości, w wyniku długotrwałego funkcjonowania systemu korporacyjnego i głębokiego przekształcenia ludzkiej natury), był homo corporativus, który w przeciwieństwie do homo economicus nie jest egoistyczna, odizolowana od życia społecznego jednostka, lecz działa w interesie społecznym, wskazanym przez państwo i korporację, do której należy. W praktyce korporatyzacja portugalskiej gospodarki nigdy się nie dokonała. „Nie istniała portugalska ekonomia korporacyjna na poziomie teoretycznym; nie było jej także na poziomie praktycznym czy w obszarze instytucjonalnym"58. Nie była to gospodarka korporacyjna, lecz jedynie sterowana, zinstytucjonalizowana i zbiurokratyzowana. Jej biurokratyzację generował hierarchiczny system korporacyjny, w którym uprawnienia decyzyjne były przekazywane na jego wyższe szczeble. Była ona w Nowym Państwie „technologią rządzenia, triumfem funkcjonariuszy i szańcem państwa”.

Niemniej trzeba zauważyć, że korporacyjna organizacja portugalskiego życia ekonomicznego, wbrew jej krępowaniu przez biurokratyczne mechanizmy scentralizowanego zarządzania, przynosiła pozytywne efekty. Dobrym przygotowaniem warunków funkcjonowania życia gospodarczego była przeprowadzona przez Salazara, jako ministra finansów (1928-1940), reforma systemu podatkowego, uzdrowienie finansów państwa oraz wprowadzenie przezeń zasady gospodarczej samowystarczalności kraju, która, jak się rychło okazało, uodporniła portugalska gospodarkę na wstrząsy międzynarodowego kryzysu finansowego z lat 1929-1932. Zastosowane wówczas ekonomiczne mechanizmy

${ }^{56}$ C. Bastien, J.L. Cardoso, From "homo economicus" to "homo corporativus". A Neglected Critique of Neoclassical Economics, „The Journal of Socio-Economics” 36, 2007, s. 121.

57 Tamże, s. 123.

58 Á. Garrido, Estado Novo e corporativismo: um programa de investigação em história económica e das instituições, w: Novos combates pela História, red. M.M. Tavares Ribeiro, Coimbra 2010, s. 303.

${ }_{59}$ N.L. Madureira, O Estado, o patronato e a indústria portuguesa (1922-1957), „Análise Social” 33, 1998, nr 148, s. 790. 
planowania i interwencjonizmu (protekcjonizmu) państwowego, mające na celu ochronę rynku wewnętrznego, z którego wyeliminowano zasadę wolnej konkurencji, stały się podstawą organizacji życia gospodarczego w Nowym Państwie. Po II wojnie światowej nastapił w Portugalii wyraźny wzrost gospodarczy, z jego „złotą epoką” w latach 50. i 60. Coraz mocniej zaznaczał się rozwój przemysłu, natomiast rolnictwo, stanowiące wcześniej podstawę portugalskiej gospodarki, stawało się sektorem jedynie wspomagajacym przemysł. Kierunek i natężenie tej transformacji odzwierciedla ewolucja struktury PKB: udział produkcji rolniczej w PKB zmniejszył się z 41\% w 1938 r. do 31\% w 1958 r., natomiast przemysłu wzrósł z 14\% w 1938 r. do 18\% w 1958 r. ${ }^{60}$ Okresem szczególnie dynamicznego wzrostu gospodarczego w Portugalii były lata 1958-1973. W ciagu tych 15 lat wartość PKB niemal się potroiła. Rolnictwo, w którym w 1958 r. pracowało 43\% populacji Portugalii i którego udział w PKB wynosił wówczas 31\%, w 1973 r. dawało zatrudnienie 34\% ludności, a jego udział w PKB stanowił 16\%. Systematycznie zwiększały się także wydatki budżetu państwa na cele socjalne (takie jak budownictwo mieszkaniowe, edukacja, ochrona zdrowia). W latach 1935-1945 nie przekraczały one $0,5 \% \mathrm{PKB}, \mathrm{w} 1960 \mathrm{r}$. osiagnęły poziom $2,6 \% \mathrm{PKB}$, a po reformie opieki społecznej (1962) wzrosły do 4\% w 1969 r., osiagając w $1974 \mathrm{r}$. pułap 6\% $\mathrm{PKB}^{61}$. Znaczącego zwrotu w kierunku państwa socjalnego dokonał Caetano, dla którego kwestie społeczne były centralnym elementem strategii politycznej.

Wprowadzanie systemu korporacyjnego rzadko spotykało się z otwartym protestem. Jedynym bardziej znaczącym wydarzeniem tego rodzaju był strajk rybaków i ludzi morza. W 1935 r., pod kuratela SCPS i nadzorem INTP, Grémio dos Armadores de Navios de Pesca do Bacalhau (Gildia Armatorów Statków Rybackich do Połowów Dorsza) narzuciła jednolity model (regulamin) rekrutowania załóg łodzi rybackich przez armatorów. W 1937 r., kiedy weszły w życie te zasady, rybacy zorganizowali masowy strajk (pierwszy i ostatni strajk tej grupy zawodowej w czasach salazaryzmu ${ }^{62}$ ), regulamin ten został bowiem przyjęty przez rybaków jako akt arogancji, „podważający praktyki społeczne

${ }^{60}$ J.L.C. das Neves, $O$ crescimento económico português no pós-guerra: um quadro global, „Análise Social” 29, 1994, nr 128, s. 1017.

${ }^{61}$ D.F. Carolo, J.A. Pereirinha, The Development of the Welfare State in Portugal. Trends in Social Expenditure between 1938 and 2003, „Revista de Historia Económica - Journal of Iberian and Latin American Economic History" 28, 2010, nr 3, s. 478-481.

${ }^{62}$ Zgodnie z dekretem nr 23203 z 6 XI 1933 r. strajk był uznawany za przestępstwo polityczne; zob. też F. Patriarca, A regulamentação de trabalho nos primeiros anos do regime corporativo, „Análise Social” 29, 1994, nr 128, s. 801. 
mocno zakorzenione wśród mężczyzn, którzy wyprawiali się po dorsze"63. Strajk trwał od stycznia do połowy maja i był najdłuższym protestem tego rodzaju w okresie Nowego Państwa. Nie miał on charakteru rewolucyjnego ani nie cechował się aktami spektakularnej przemocy ze strony sił policyjnych. Część najbardziej aktywnych uczestników strajku została aresztowana. Ostatecznie rybacy zaokrętowali się na kutry na nowych zasadach - jedni dobrowolnie, inni, aresztowani podczas strajku, pod eskorta policji (w imię interesu narodowego).

Wadliwe funkcjonowanie systemu korporacyjnego było dostrzegane także przez władze państwowe. W 1945 r. Zgromadzenie Narodowe zleciło powołanej przez nie komisji sporządzenie raportu na ten temat. Był on krytyczny w odniesieniu do funkcjonowania większej części organizmów systemu korporacyjnego, zwłaszcza domów ludowych. Wykazywał, że ich działalność nie jest atrakcyjna dla mieszkańców wsi, zwłaszcza ze względu na rolę, jaka odgrywali w nich przedstawiciele miejscowej elity, będący częściej czynnikiem rozkładu lokalnej społeczności i obniżenia jej prestiżu niż jej spoiwem ${ }^{64}$. Fundusze domów ludowych były całkowicie kontrolowane przez właścicieli ziemskich, tak iż dochodziło do ich skandalicznego wykorzystywania przez nich do własnych celów. W obliczu możliwości niemal całkowitego wygaśnięcia działalności domów ludowych, w celu podniesienia jej na wyższy poziom i jej koordynacji, w 1945 r. (dekretem nr 34373 z 10 stycznia) powołano Junta Central das Casas do Povo (Centralny Zarząd Domów Ludowych). Kolejnym ważnym krokiem w kierunku konsolidacji systemu korporacyjnego w odniesieniu do domów ludowych i ich federacji była przeprowadzona w 1969 r. ich reorganizacja. Fundusz domów ludowych, zwłaszcza w zakresie ubezpieczeń powypadkowych oraz zasiłków wypłacanych osobom znajdującym się w trudnej sytuacji życiowej, został znacznie zasilony przez państwo. Spowodowało to znaczący wzrost liczby domów ludowych, głównie na północy i w centrum kraju, gdzie ich sieć rozwijała się wolniej niż na południu kraju.

Likwidacja systemu korporacyjnego w Portugalii po rewolucji goździków w 1974 r. stanowiła długi i złożony proces ${ }^{65}$. Niektóre jego organy wykazały się dużą zdolnością adaptacyjną do nowych warunków politycznych. Po 1974 r. utrzymano istnienie domów ludowych, a nawet utworzono nowe. Istnieją one do dzisiaj, chociaż spełniają inne funkcje

${ }^{63}$ Á. Garrido, Os bacalhoeiros em revolta: a „greve” de 1937, „Análise Social” 37, 2003, nr 165, s. 1197.

${ }^{64}$ D. Freire, dz. cyt., s. 280-281.

${ }_{65}$ M. de Lucena, A revolução portuguesa: do desmantelamento da organização corporative ao duvidoso fim do corporativismo, „Análise Social” 13, 1977, nr 51, s. 543. 
niż te, do których były powołane (są one obecnie głównie ośrodkami kultury i opieki); dekret nr 737/74 z 1974 r. pozbawiał je funkcji reprezentacji zawodowej robotników rolnych. Zlikwidowano natomiast najwyższe organizmy systemu - korporacje, INTP (dekret nr 760/74) i Izbę Korporacyjna w parlamencie oraz wiele instytucji pośrednich (m.in. obligatoryjne gildie). Niektóre organy spełniające funkcje koordynacji ekonomicznej rozwiąano, inne przekształcono w spółki, a jeszcze inne, poddane różnym modyfikacjom, istniały do połowy lat 80. Proces likwidacji instytucji korporacyjnych trwał do początków bieżącego stulecia. W Portugalii jeszcze długo istniały instytucje spełniające ekonomiczne funkcje regulacyjne, będące spadkobiercami organów Nowego Państwa, bowiem „dekady życia w systemie autokratycznym pozostawiły ślad na formach, w jakich czynniki ekonomiczne sa powiązane z państwem" ${ }^{\prime \prime}$. Nowo powołane organizmy tego rodzaju nie różniły się znacząco od wcześniejszych; chociaż częściowo zmieniono ich kierownictwo, to jeszcze w latach 90. utrzymywały one swój dawny stan posiadania. W owym czasie Manuel de Lucena i Carlos Gaspar zauważali, że „odzyskanie przez państwo demokratyczne i przez »wszystkie« aktualnie działajace wielkie partie tak licznych wyższych kadr Nowego Państwa (technicznych, administracyjnych i korporacyjnych), a także części jego personelu politycznego - łącznie $\mathrm{z}$ eksministrami - z pewnością nie jest dziełem przypadku. Tak jak być może dziełem przypadku nie jest to, że wielu głównych autorów i interpretatorów konstytucji z 1976 r. oraz nowych przepisów prawa socjalnego to wdzięczni uczniowie następcy Salazara”" ${ }^{67}$.

\section{Zakończenie}

Jednym z pierwszorzędnych celów podjęcia przez Salazara idei budowy ustroju autokratycznego (dyktatury) była kontrola świata pracy przez państwo, a nawet, jak to ujmują Janina Pałęcka i Oskar Sobański, „kontrola nad wszelkimi przejawami aktywności społeczno-politycznej obywateli pod szyldem "ugody społecznej« i zaniku walki klasowej"68. Jak się niekiedy zauważa, system korporacyjny Nowego Państwa był elementem „sztuki trwania” (a arte de saber durar) Salazara:

${ }^{66}$ O. Simões, dz. cyt., s. 617.

${ }^{67}$ M. de Lucena, C. Gaspar, Metamorfoses corporativas? Associações de interesses e institucionalização da democracia (I), „Análise Social” 26, 1991, nr 114, s. 851.

68 J. Pałęcka, O. Sobański, Rewolucja nie zaczęła się w czwartek, Warszawa 1976, s. $79-80$. 
politycznym i administracyjnym narzędziem Nowego Państwa, wykorzystywanym [...] do realizacji potrójnego strategicznego celu: lokalizowania, demontażu i tłumienia prób wyrażania żądań przez pracowników, gwarantując politycznie niski nominalny i realny koszt pracy; dekretowania, w imię ,interesu narodowego", że reżim będzie jedynym i jednostronnym interpretatorem sprzeczności interesów między dominującymi sektorami oligarchii ekonomicznej i społecznej ${ }^{69}$.

System ten skutecznie zniechęcał obywateli do aktywności. To ich apatia pozwalała salazaryzmowi (,salazarchii”) trwać przez ponad 40 lat $^{70}$. W praktyce okazał się on narzędziem władania państwa nad społeczeństwem, wykorzystywanym do tłumienia konfliktów społecznych i niedopuszczania do otwartej konfrontacji interesów, i nie przyczynił się do utworzenia społeczeństwa bardziej wolnego i autonomicznego niż to, którego model Nowe Państwo odrzuciło jako sprzeczny z interesami narodu i swoich obywateli. W $1974 \mathrm{r}$. w rewolucyjnym zrywie, przełamując apatię, sprzeciwili się oni dalszemu trwaniu tego stanu rzeczy, przywracając w Portugalii liberalne zasady życia społecznego.

\section{Bibliografia}

Amaro A.R., O modelo político administrativo do Estado Novo português. Corporativismo e representação política das autarquias (1936-1959), „Espacio Tiempo y Forma. Serie V. Historia Contemporánea” 27, 2015, s. 85-106.

Barreto J., Comunistas, católicos e os sindicatos sob Salazar, „Análise Social” 29, 1994, nr 125-126, s. 287-317.

Bastien C., Cardoso J.L., From "homo economicus" to "homo corporativus". A Neglected Critique of Neoclassical Economics, „The Journal of Socio-Economics" 36, 2007, s. 287-317.

Bernal García F., Corporativismo y Fascismo. Los sistemas de relaciones laborales autoritarios en la Europa de entreguerras, „Hispania Nova” 15, 2017, s. $45-75$.

Borges Santos P., O modelo político do estado autoritário português. A ideia corporativa na constitucionalização do regime (1931-1933), „Espacio Tiempo y Forma. Serie V. Historia Contemporánea” 27, 2015, s. 59-84.

${ }^{69}$ L. Aronne de Abreu, P. Borges Santos, Corporativismo e Salazarismo em perspectiva: o olhar de Fernando Rosas, „Estudos Ibero-Americanos” 42, 2016, nr 2, s. 556; zob. N.M. Magalhães Pereira, Nós, o povo: as redes das casas do povo nos alinhamentos corporativos (1933-1974), „Oficina do Historiador” 9, 2016, nr 2, s. 99-100.

${ }^{70}$ Zob. F. Rosas, Salazar e o poder. A arte de saber durar, Lisboa 2012; J. Firstenberg Riegelhaupt, Os camponeses e a política no Portugal de Salazar - o Estado Corporativo eo „apoliticismo” nas aldeias, „Análise Social” 15, 1979, nr 59, s. 523; Á. Garrido, O Estado Novo português e a institucionalização..., s. 306. 
Costa Pinto A., Corporatism and Dictatorships in Portugal and Spain. Comparative Perspectives, w: Cola, Zeitgeschichte: Oliver Rathkolb und das lange 20. Jahrhundert, t. 1, red. L. Dreidemy, R. Hufschmied, A Meisinger i in., Wien 2015, s. 489-504.

Decreto n. ${ }^{\circ} 22241$, Constituição Política da República Portuguesa, Diário do Govêrno n. ${ }^{\circ}$ 43/1933, $1^{\circ}$ Suplemento, Série I de 22.02.1933.

Decreto-lei 23048, Estatuto do Trabalho Nacional, Diário do Govêrno n. ${ }^{\circ}$ 217/1933, Série I de 23.09.1933.

Freire D., Estado Corporativo em acção: sociedade rural e construção da rede de Casas do Povo, w: Corporativismo, Fascismos, Estado Novo, red. F. Rosas, Á. Garrido, Coimbra 2012, s. 273-302.

Garrido Á., „A terra e o mar não se sindicalizam!”. As Casas dos Pescadores no sistema corporativo do Estado Novo português (1933-1968), w: Tra due crisi. Urbanizzazione, mutamenti sociali e cultura di massa tra gli anni Trenta e gli anni Settanta, red. M. Pasetti, Bologna 2013, s. 87-110.

Lucena M. de, A revolução portuguesa: do desmantelamento da organização corporative ao duvidoso fim do corporativismo, „Análise Social” 13, 1977, s. 541-592.

Magalhães Pereira N.M., Nós, o povo: as redes das casas do povo nos alinhamentos corporativos (1933-1974), „Oficina do Historiador” 9, 2016, s. 99-118.

Neves J.L.C. das, O crescimento económico português no pós-guerra: um quadro global, „Análise Social” 29, 1994, nr 128, s. 1005-1034.

Patriarca F., A institucionalização corporativa - das associações de classe aos sindicatos nacionais (1933), „Análise Social” 26, 1991, nr 110, s. 23-58.

Reis Torgal L., „Crise” e „crises” no discurso de Salazar, „Estudos do Século XX” 10, 2010, s. 397-419.

Rezola M.I., Católicos, operários e sindicatos, „Lusitania Sacra” 6, 1994, s. $101-127$.

Salazar A., Rewolucja pokojowa, tłum. Z. Grabski, Warszawa 2013.

Mieczysław Jagłowski

The corporate system of the Portuguese New State (1933-1974)

(Summary)

The article presents the political circumstances of the establishment and functioning of the corporate system of the Portuguese New State (1933-1974), being one of the longest lasting in modern Europe (for over forty years) socio-political structures of this type. The political background (both European and Portuguese one) is sketched out, together with the social and ideological circumstances of the system implementation; a large part of the text is devoted to the arguments for its establishment put forth by the chief advocate and author of the Portuguese corporate system, António de Oliveira Salazar. There 
are also opinions of the project's critics cited. Then, the author presents a corporate structure of the New State, established in 1933, together with its cells and institutions; and indicates the legal acts by which it was created and remodelled. Next, the attitudes towards the corporate system of the politically most active social circles, ideological options, and professional groups. On the basis of the establishments, the author describes social, political, and economic results of the corporate organisation of social life in Portugal, and sketches out the circumstances of its abolishment after the Carnation Revolution (1974).

Mieczysław Jagłowski - prof. dr hab., pracownik Instytutu Filozofii Uniwersytetu Warmińsko-Mazurskiego w Olsztynie. Zainteresowania badawcze: dzieje hiszpańskiej i latynoamerykańskiej myśli filozoficznej, społecznej i religijnej, portugalskie imaginarium narodowo-polityczne. Opublikował m.in. monografie: Życie i rozum. Filozofia racjowitalizmu Juliána Maríasa, Olsztyn 1998; Realizm transcendentalny Xaviera Zubiriego, Olsztyn 2000; María Zambrano: anamneza i filozofia poetyckiego zbawienia, Torun 2009; Zarys historii filozofii hiszpańskiej. Nurty i szkoty, Olsztyn 2013.

Mieczysław Jagłowski - Prof. Dr. hab., employed at the Institute of Philosophy of the University of Warmia and Mazury in Olsztyn; his research interests cover: the history of Spanish and Latin-American philosophical, social, and religious thought, Portuguese national-political imaginarium. He is the author of, among others, monographs: Życie i rozum. Filozofia racjowitalizmu Juliána Maríasa (The Life and Reason. Julián Marías' Ratio-Vitalism Philosophy, Olsztyn, 1998); Realizm transcendentalny Xaviera Zubiriego (Transcendental Realism of Xavier Zubiri, Olsztyn, 2000); María Zambrano: anamneza i filozofia poetyckiego zbawienia (María Zambrano: Anamnesis and Philosophy of Poetic Salvation, Torun, 2009), Zarys historii filozofii hiszpańskiej. Nurty $i$ szkoty (An Outline of the History of Spanish Philosophy. Trends and Schools, Olsztyn, 2013).

E-mail:mjag@uwm.edu.pl. 